\title{
Circulating biomarkers of oxidative stress in chronic obstructive pulmonary disease: a systematic review
}

\author{
Elisabetta Zinellu', Angelo Zinellu², Alessandro Giuseppe Fois ${ }^{1}$, Ciriaco Carru ${ }^{3}$ and Pietro Pirina ${ }^{1 *}$ (D
}

\begin{abstract}
Chronic obstructive pulmonary disease (COPD) is a progressive condition characterized by aiffow limitation associated with an abnormal inflammatory response of the lungs to noxious particles and gases, caused primarily by cigarette smoking. Increased oxidative burden plays an important role in the pathogenesis of COPD. There is a delicate balance between the toxicity of oxidants and the protective function of the intracellular and extracellular antioxidant defense systems, which is critically important for the maintenance of normal pulmonary functions. Several biomarkers of oxidative stress are available and have been evaluated in COPD. In this review, we summarize the main literature findings about circulating oxidative stress biomarkers, grouped according to their method of detection, measured in COPD subjects.
\end{abstract}

Keywords: Chronic obstructive pulmonary disease, Biomarkers, Oxidative stress, Peripheral blood

\section{Background}

COPD is a major and increasing global health problem and is currently the third leading cause of death in the world [1].

COPD is defined as a preventable and treatable disease characterized by persistent airflow limitation that is not fully reversible [2]. The airflow limitation is usually progressive and associated with an enhanced chronic inflammatory response of the airways and the lungs to noxious particles or gases. Exacerbations and comorbidities contribute to the overall severity in individual patients $[2,3]$. COPD results from the interplay between genetic susceptibility and exposure to environmental stimuli [4]. A well established genetic cause of COPD is $\alpha_{1}$ antitrypsin deficiency [5] whereas, among environmental stimuli, cigarette smoking is the main cause. Other exposures, such as outdoor air pollution, occupational exposure to dusts and fumes, exposure to secondhand smoke, and biomass smoke inhalation might increase the risk of and lead to disease in nonsmokers $[6,7]$. Cigarette smoke in particular contains $10^{17}$

\footnotetext{
* Correspondence: pirina@uniss.it

${ }^{1}$ Department of Respiratory Diseases, Azienda Ospedaliero Universitaria di Sassari, Sassari, Italy

Full list of author information is available at the end of the article
}

oxidant molecules per puff [8]. Such exposure causes direct injury of airway epithelial cells leading to airway inflammation in which a variety of cells such as neutrophils, macrophages and lymphocytes, are involved. Proteolytic enzymes and reactive oxygen species (ROS) are released and, if not sufficiently counterbalanced by antiproteases and antioxidant factors, will produce further damage [9]. The term ROS indicates a large variety of free oxygen radicals such as superoxide anion $\left(\mathrm{O}_{2}^{-}\right)$and hydroxyl radical $\left(\mathrm{OH}^{-}\right)$, but also derivatives of oxygen that do not contain unpaired electrons, such as hydrogen peroxide $\left(\mathrm{H}_{2} \mathrm{O}_{2}\right)$. Formation of ROS takes place constantly in every cell during normal metabolic processes. Moreover, activated phagocytic cells such as neutrophils and macrophages produce large amounts of ROS when are stimulated by encounter inhaled particles or other mediators of inflammation [10]. When ROS are produced in excess of the antioxidant defense mechanisms, oxidative stress occurs resulting in harmful effects, including damage to lipids, proteins and DNA. Although the pathogenesis of COPD remains incompletely understood, the central role of oxidative stress in this regard is well established (Fig. 1) [11-14].

Several biomarkers of oxidative stress are available, including ROS themselves. Since ROS are generally too 


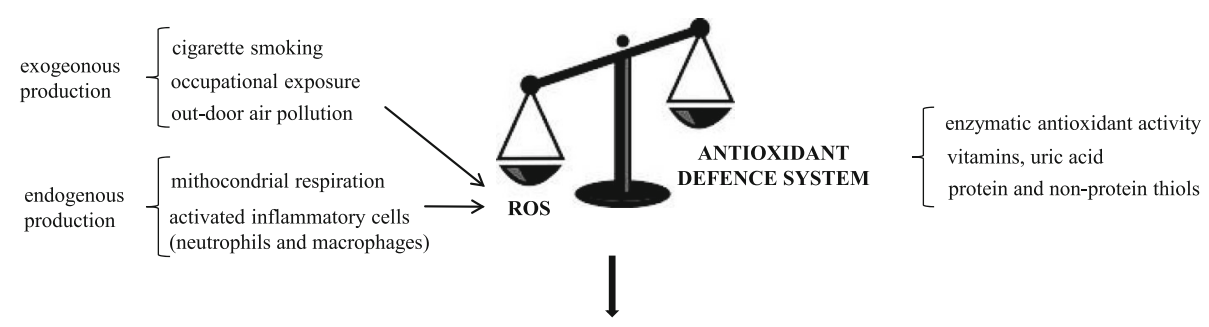

OXIDATIVE STRESS

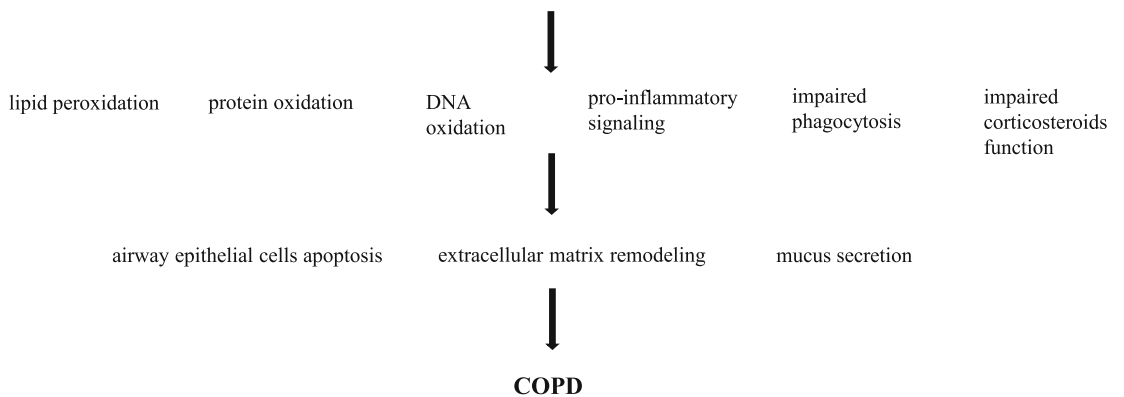

Fig. 1 A mechanism showing the central role of oxidative stress in the pathophisiology of COPD. The imbalance between oxidants and antioxidants in favor of oxidants leads to harmful damage. Oxidative stress amplifies the inflammatory response influencing intracellular signaling pathways that drive the release of inflammatory mediators, impairing fagocytosis of apoptotic cells and weakening the ability of corticosteroids to repress proinflammatory genes expression. Inflammation, lipid peroxidation, protein oxidation and DNA damage results in tissue damage,

alteration of protein functions and gene expression, remodeling of extracellular matrix and mucus secretion

reactive and have a half-life too short to allow their direct measurement in tissues or body fluids, it is more suitable to estimate oxidative stress by measuring their oxidation target products, including lipid peroxidation end products and oxidized proteins, as well as various antioxidants [15]. Regarding COPD, various biomarkers of oxidative stress have been evaluated, both oxidant and antioxidant markers. In this review we summarize the main findings about oxidative stress biomarkers grouped according to their method of detection, evaluated in the blood of COPD patients compared to healthy controls as well as in different stages of the disease. The majority of these studies have considered from mild to very severe COPD while very few studies, to our knowledge, have considered only mild COPD subjects for their analysis.

\section{Lipid peroxidation products}

Lipid peroxidation is the major consequence of oxidative stress and cause of oxidative damage [16].

Many evidences show the association between the levels of these biomarkers and the development of various diseases [15, 17, 18]. Accordingly, lipid peroxidation products have received much attention as biomarkers of oxidative stress.

Lipids are vulnerable to oxidation by both enzymes and nonenzymatic oxidants. The mechanisms and products of lipid peroxidation have been studied extensively $[19,20]$. Polyunsaturated fatty acids are very reactive toward oxygen radicals and readily oxidized to produce lipid hydroperoxides and various aldehydes as major products. Cholesterol is also an important substrate of oxidation and its oxidation products are also studied as biomarkers of oxidative stress [21].

Various biomarkers of lipid peroxidation have been developed and applied to biological samples [22]. Among these, malondialdehyde (MDA) and thiobarbituric acid reactive substances (TBARS) remain among the most commonly applied indices of oxidative damage [23, 24]. Several studies have investigated MDA as potential biomarker to assess oxidative stress status in COPD patients using the method of TBARS that involves the reaction of MDA with thiobarbituric acid (TBA) under strong acidic condition and heating, leading to the formation of an adduct which can be easily assessed with a spectrophotometer. One of the most consistent finding across many of these studies was a significant increase in TBARS MDA in COPD patients compared to healthy controls [25-45] (Table 1). Moreover, using this kind of approach some authors have investigated the levels of plasma MDA in parallel with the progression of the disease, observing both an increase with increasing severity of the disease [26, 29, 46, 47] and no differences [40] (Table 1).

Conversely, few other authors did not find a significant difference in plasma TBARS MDA of COPD patients compared to healthy controls [48-53] (Table 1), while others described a significant increase during acute exacerbations and a return to values comparable to those of 
Table 1 Summary of the most abundant findings about oxidative stress biomarkers in COPD

\begin{tabular}{|c|c|c|c|}
\hline Oxidative stress biomarker & Method of detection & A & B \\
\hline \multirow[t]{4}{*}{$\overline{\mathrm{MDA}}$} & spectrophotometer, following reaction with TBA & $\uparrow^{25-45} /$ n.d. ${ }^{48-53,55}$ & $\uparrow^{26,29,46,47} /$ n.d. $^{40}$ \\
\hline & HPLC, following reaction with TBA & $\uparrow^{56,57}$ & \\
\hline & HPLC & $\uparrow^{58}$ & \\
\hline & $\begin{array}{l}\text { spectrophotometer, following reaction with 1-methyl-2- } \\
\text { phenylindole }\end{array}$ & $\uparrow^{59-61}$ & $\uparrow^{59,60}$ \\
\hline \multirow[t]{2}{*}{ Lipid peroxides } & spectrophotometer, in a solution containing cholesterol-iodide & $\uparrow^{59}$ & \\
\hline & spectrophotometer, following reaction with peroxidase & $\uparrow^{62}$ & \\
\hline Coniugated dienes & spectrophotometer & $\uparrow^{27,59}$ & \\
\hline Oxidized LDL & specific enzyme immunoassay & $\uparrow^{62}$ & \\
\hline 8-isoprostane & specific enzyme immunoassay & $\uparrow^{63}$ & \\
\hline \multirow[t]{3}{*}{ Protein carbonyls } & spectrophotometer, following the reaction with DNPH & $\uparrow^{29,35,36,40,59,60,69} /$ n.d. ${ }^{73}$ & $\uparrow^{59} / \mathrm{n} \cdot \mathrm{d}^{29,36,40}$ \\
\hline & immunochemically, following the reaction with DNPH & $\uparrow^{46,70,71 / \text { n.d. }}{ }^{72}$ & \\
\hline & labeling with tritiated borohydride & $\uparrow^{52}$ & $\uparrow^{53}$ \\
\hline AOPP & spectrophotometer & $\uparrow^{32,40} /$ n. $d^{49}$ & n.d ${ }^{40}$ \\
\hline \multirow[t]{3}{*}{ Protein SH groups } & following reaction with Ellman's reagent & $\downarrow^{29,30,36,55,92} /$ n.d. $^{39}$ & n.d ${ }^{29,36}$ \\
\hline & measuring albumin on a chemistry automated analyzer & $\downarrow^{56}$ & \\
\hline & subtracting GSH from total thiols & $\downarrow^{53} / n \cdot d^{40}$ & \\
\hline Plasma reduced GSH & following reaction with Ellman's reagent & $\downarrow^{28,34,40,41,43,45,53} /$ n.d ${ }^{55,72}$ & n.d ${ }^{40}$ \\
\hline Plasma total glutathione & $\begin{array}{l}\text { following reaction with Ellman's reagent and glutathione } \\
\text { reductase }\end{array}$ & & n.d ${ }^{47}$ \\
\hline Plasma total/oxidized glutathione ratio & $\begin{array}{l}\text { following reaction with Ellman's reagent with glutathione } \\
\text { reductase and 1-methyl-2-vinylpyridine }\end{array}$ & n.d ${ }^{95}$ & \\
\hline \multirow[t]{2}{*}{ Erythrocyte reduced GSH } & following reaction with Ellman's reagent & $\downarrow^{26,37}$ & $\downarrow^{26}$ \\
\hline & following reaction with a reagent different from Ellman's & n.d. ${ }^{48}$ & \\
\hline Whole blood total glutathione & $\begin{array}{l}\text { following reaction with Ellman's reagent with glutathione } \\
\text { reductase and 2-vinylpyridine }\end{array}$ & $\uparrow^{29,36}$ & $\uparrow^{29}$ \\
\hline Plasma total thiols & following reaction with Ellman's reagent & $\downarrow^{51 / \uparrow^{69}}$ & $\downarrow^{40}$ \\
\hline \multirow[t]{4}{*}{ Erythrocytic SOD activity } & Mc Cord and Fridovich assay & $\uparrow^{36,69} / \downarrow^{98,99} /$ n.d. $^{33}$ & n.d ${ }^{46}$ \\
\hline & Misra and Fridovich assay & $\downarrow^{27} / \uparrow^{27}$ & \\
\hline & Marklund and Marklund assay & $\downarrow^{29} /$ n.d $d^{40}$ & \\
\hline & Das K. assay & $\downarrow^{30}$ & \\
\hline \multirow[t]{2}{*}{ Plasma SOD activity } & Mc Cord and Fridovich assay & $\uparrow^{61} / \downarrow^{32,41} /$ n.d ${ }^{70,71}$ & n.d ${ }^{47}$ \\
\hline & ELISA & $\downarrow^{105}$ & \\
\hline Erythrocytic CAT activity & monitoring the decomposition rate of $\mathrm{H}_{2} \mathrm{O}_{2}$ & $\downarrow^{26,29,98,99} / n \cdot d^{27,33,36,40}$ & $\downarrow^{26} / n \cdot d^{40,46}$ \\
\hline \multirow[t]{2}{*}{ Plasma CAT activity } & monitoring the decomposition rate of $\mathrm{H}_{2} \mathrm{O}_{2}$ & $\downarrow^{34,43 / n} \cdot d^{47,71}$ & \\
\hline & ELISA & n.d $d^{105}$ & \\
\hline Erythrocytic GSHPx activity & evaluating the oxidation of $\mathrm{NADPH}$ & $\downarrow^{26,27,29,33,36,98}$ & $\downarrow^{46,106}$ \\
\hline \multirow[t]{2}{*}{ Plasma GSHPx activity } & evaluating the oxidation of $\mathrm{NADPH}$ & $\downarrow^{34,41,43 / \uparrow^{36,105} / \text { n.d. }}{ }^{61}$ & \\
\hline & assaying the content of reduced glutathione & $\uparrow^{40}$ & \\
\hline Whole blood GSHPx activity & evaluating the oxidation of $\mathrm{NADPH}$ & $\downarrow^{69}$ & \\
\hline
\end{tabular}

Compared to healthy controls (column A) and in different stages of COPD (column B). $\uparrow$ : increased levels; $\downarrow$ : reduced levels; n.d.: no significant difference

controls by the time of discharge after treatment [54]. We investigated MDA levels considering only mild COPD, finding no differences between patients and controls [55] (Table 1). Some authors have analyzed MDA measuring TBA-MDA adduct with high performance liquid chromatography (HPLC) rather than spectrophotometer and finding a significant increase of this biomarker in COPD compared to healthy controls [56, 57] (Table 1). Moreover, measuring free MDA, not as TBA-MDA adduct, by means of HPLC using an 
ultraviolet spectrophotometric detector at the wavelength of $254 \mathrm{~nm}$, a significant increase of this biomarker has also been found in exacerbated COPD, as well as after treatment of the exacerbation compared to healthy controls [58] (Table 1).

By using a different assay that involves 1-methyl-2-phenylindole, that under acidic and mild-temperature conditions reacts with MDA to yield a stable chromophore with maximal absorbance at $586 \mathrm{~nm}$, an increase of plasma MDA levels has been described [59-61], in some cases also in relation to disease progression $[59,60]$ (Table 1).

To a lesser extent than MDA, other biomarkers of lipid peroxidation have been studied in plasma of COPD patients of which have been described increased levels compared to controls (Table 1): lipid peroxides, determined spectrophotometrically either using their ability to convert iodide to iodine in a solution containing cholesterol-iodide [59] or following their reaction with peroxidase and a subsequent color production [62]; conjugated dienes, that are formed in the process of lipid peroxidation as a result of a reconfiguration of double bonds and yield a characteristic absorbance peak [27, 59]; oxidized LDL, determined spectrophotometrically with a competitive enzyme-linked immunosorbent assay (ELISA) kit [62] and 8-isoprostane, assayed with a specific enzyme immunoassay kit [63].

\section{Protein oxidation products}

The most abundant byproduct of oxidative damage of proteins is protein carbonylation [64]. The presence of carbonyl groups in proteins is therefore the most commonly used marker of ROS mediated protein oxidation $[64,65]$, and accumulation of protein carbonyls has been observed in several human diseases $[64,66,67]$.

Specifically, carbonyl derivatives (aldehydes and ketones) are formed by reaction of oxidants with lysine, arginine, proline, and threonine residues of the protein side-chains. Moreover, direct reactions of proteins with ROS may also lead to the formation of peptide fragments containing highly reactive carbonyl groups. Proteins containing reactive carbonyl groups can also be generated by secondary reactions of lysine residues of proteins with reducing sugars or their oxidation products and also by reactions of lysine, cysteine, or histidine residues with unsaturated aldehydes formed during the peroxidation of poly-unsaturated fatty acids [68].

The most common and reliable method for determination of carbonyl content is based on the reaction of carbonyl groups with 2,4-dinitrophenylhydrazine (DNPH), which leads to the formation of a stable dinitrophenylhydrazone (DNP) product that can then be detected and quantified spectrophotometrically at $370 \mathrm{~nm}$ or immunochemically using specific antibodies to antiDNP [67].
The approach based on the reaction of carbonyl groups with DNPH has been used in several studies to investigate protein carbonylation levels in the plasma of COPD patients, both detecting DNP product spectrophotometrically $[29,35,36,40,59,60,69]$ and immunochemically [46, 70, 71] (Table 1). All of these studies have described a significant increase of protein carbonyl groups in plasma of COPD patients, that sometimes [59], but not always $[29,36,40]$ proceeds in parallel with the progression of the disease (Table 1). On the other hand, few other studies observed no differences in this biomarker levels using the same kind of approach $[72,73]$ (Table 1).

However, a significant increase in plasma protein carbonylation levels has been described also using another kind of assay, that is by labeling protein carbonyl groups with tritiated borohydride [52] (Table 1). In this study the authors described an increase in the amount of plasma carbonyls in parallel with the progression of COPD. To estimate the degree of oxidant-mediated protein damage in plasma of COPD patients, the presence of advanced oxidation protein products (AOPP) has also been investigated. AOPPs are a family of oxidized, dityrosine-containing, cross linked protein compounds formed by the reaction of plasma proteins, especially albumin, with chlorinated oxidants [74]. Measuring this parameter in a spectrophotometer on a microplate reader [75], both an increase [32, 40] and no difference [49] has been described in plasma of COPD patients compared to controls (Table 1). This marker has been considered in the course of disease progression too, finding no difference throughout the stages of the disease [40] (Table 1).

\section{Reactive oxygen species (ROS)}

Some authors have investigated the production of ROS, in particular $\mathrm{O}_{2}^{-}$, to explore the levels of oxidative stress in the plasma of COPD patients. A method frequently used to detect $\mathrm{O}_{2}^{-}$is based on chemiluminescence. On exposure to $\mathrm{O}_{2}^{-}$, chemiluminescent probes release a photon, which in turn can be detected by a scintillation counter or a luminometer [76]. Using lucigenin as chemiluminescent probe, an increase in $\mathrm{O}_{2}^{-}$production has been described in COPD patients compared to healthy controls $[49,50,70]$. An increase in $\mathrm{O}_{2}^{-}$production has also been described using enzymatic assays based on measuring the SOD-inhibitable reduction of cytochrome c determined in a spectrophotometer by the increase in absorbance at $550 \mathrm{~nm}[36,39]$ or using nitroblue tetrazolium that undergoes reduction by $\mathrm{O}_{2}^{-}$to form diformazan, a dark insoluble precipitate [32].

\section{Total oxidative status}

Instead of measuring different oxidant species separately, some authors have studied total oxidative status (TOS) in plasma of COPD patients as a marker of oxidative 
stress, named also total peroxide (TP) or reactive oxygen metabolites (ROMs) [77].

TOS can be evaluated by means of an assay based on the oxidation of ferrous ion to ferric ion by the oxidants present in the sample. The ferric ion makes a colored complex with xylenol orange and the color intensity can be measured spectrophotometrically. Using this assay, an increase in TOS has been described in COPD [32, 78-80]. Other authors have measured ROMs in plasma of COPD patients to test the oxidant ability of the plasma sample towards a particular substance used as an indicator. By means of the so called diacron reactive oxygen metabolites (D-ROM) test, an increase of overall ROMs has been described in COPD patients compared to controls [81, 82].

\section{Oxidatively damaged DNA}

To a lesser extent than other oxidative stress biomarkers, oxidatively damaged DNA has been studied in COPD patients as well. A sensitive method for analyzing oxidative DNA damage is the single-cell gel electrophoresis also known as comet assay, which detects strand breaks [83]. Breaks in DNA allow supercoiled loops of DNA to relax and move out to form what looks like a comet with a tail under the conditions of the assay. The proportion of DNA in the tail is indicative of the frequency of breaks. By means of this assay, a significant increase in DNA damage has been detected in COPD compared to controls [35, 40, 84].

Another commonly used marker for assessing oxidative DNA damage is 8-oxo-7,8-dihydro-2'-deoxyguanosine (8oxodG). No significant difference in levels of DNA damage, as measured by 8-oxodG by means of ELISA [71] or HPLC [57], has been found.

\section{Protein and non-protein thiols}

Thiols, are a class of organic compounds that contain a sulfhydryl group $(-\mathrm{SH})$. The plasma thiol pool is mainly formed by protein thiols and slightly formed by low molecular-weight thiols, such as cysteine, cysteinylglycine, glutathione (GSH), homocysteine, and $\gamma$-glutamylcysteine [85] and are considered a key factor in redox sensitive reactions of plasma [86].

In fact, thiols can undergo oxidation processes in the presence of oxidants to yield a wide range of products, some of which, like disulfides, can revert to thiols with suitable reductants, while others such as sulfinic and sulfonic acids constitute typically final products [85, 87]. Thus, as well as intracellular thiols, such as GSH, are essential in maintaining the highly reduced environment inside the cell, extracellular thiols also constitute an important component of the antioxidant defense system $[88,89]$.
The most abundant reduced - $\mathrm{SH}$ group in plasma is that of human serum albumin, given its high concentrations. The single free cysteinyl thiol of albumin $\mathrm{Cys}^{34}$, accounts for about $80 \%$ of reduced thiols in human plasma and is an important scavenger of reactive oxygen and nitrogen species in the vascular compartment [90].

The thiols level is most commonly measured using the classical Ellman's reagent, 5,5'-dithiobis-(2-nitrobenzoic) acid. This compound is reduced by free thiols in an exchange reaction, forming a mixed disulphide and releasing one molecule of 5-thionitrobenzoic acid, which can be measured at $412 \mathrm{~nm}$ [91]. This method of detection has been used in several studies to measure the content of both protein and non-protein $\mathrm{SH}$ groups in the peripheral blood of COPD patients.

- Protein SH groups: in this regard a significant decrease of this biomarker has been described in COPD compared to healthy controls [29, 30, 36, 92] and even in mild COPD [55] (Table 1). Some authors have investigated this biomarker in the different stages of severity of COPD finding no differences [29, 36]. Interestingly, other authors found a significant reduction of protein $\mathrm{SH}$ groups only in exacerbated COPD $[39,54]$ with a complete restoration by the time of discharge after treatment of exacerbation [54]. Measuring $\mathrm{SH}$ groups by analysis of albumin on a chemistry automated analyzer, a significant reduction of protein thiols has been detected [56] (Table 1). Moreover, measuring protein $\mathrm{SH}$ groups by subtracting the GSH content from total thiols measured with Ellman's reagent, both a significant decrease [53] and no difference between COPD and controls [40] has been detected (Table 1).

- Non-protein SH groups: this biomarker has been investigated in plasma, in whole blood and in erythrocytes. A significant decrease in non-protein $\mathrm{SH}$ groups, mainly in the form of reduced GSH, has been found in many of the examined studies $[28,34,40,41,43,45,53]$ (Table 1). No differences have been found considering only mild COPD [55] (Table 1). When investigated in the different stages of COPD severity, no difference has been found, either [40] (Table 1). Investigating total GSH (oxidized and reduced) by an assay that employs Ellman's reagent and glutathione reductase to reduce oxidize glutathione (GSSG) [93], no difference has been found in the different stages of disease severity [47] (Table 1). Regarding the levels of erythrocyte reduced GSH, a significant decrease has been described $[26,37]$ in parallel with the progression of the disease [26] (Table 1), while other authors found no significant difference in this biomarker using a reagent different 
from Ellman's to obtain a chromophoric compound which has a maximal absorbance at $400 \mathrm{~nm}$ [48]

(Table 1).

Moreover, a significant increase of total GSH, assayed in whole blood of COPD patients using the Ellman's reagent with glutathione reductase and 2-vinylpyridine to prevent oxidation of GSH during the sample preparation [94], has been described [29, 36] also in parallel with the progression of the disease [29] (Table 1). The same approach, except for using 1-methyl-2-vinylpyridine instead of 2-vinylpyridine, has been used in plasma of COPD patients to investigate total GSH/GSSG ratio and it was found significantly reduced in exacerbation compared to stable COPD, whereas no difference has been found compared to healthy controls [95] (Table 1).

Analyzing protein and non-protein $\mathrm{SH}$ groups as total thiols, a significant reduction of this marker has been found in COPD compared to controls [51], as well as with progression of the disease [40], while other authors found that the concentration of total thiols was enhanced in plasma of COPD patients compared to controls [69] (Table 1).

\section{Antioxidant nutrients}

By means of spectrophotometric or chromatographic methods, the plasmatic levels of some antioxidant nutrients such as vitamin $A, C$ and $E$ and $\alpha$ - and $\beta$-carotenes that comprise an important aspect of the antioxidant defense system evolved by humans, have been investigated. A decreased level of vitamin $C[25,28,62]$ and $E$ $[25,28,30]$, as well as no difference in the levels of vitamin A [27], C [40, 48, 95] and E [27] has been described in COPD compared to healthy controls. No differences have also been found in the different stages of severity of disease [96]. A significant reduction of vitamins A, C and $\mathrm{E}$ has been described in exacerbated COPD, with a restoration to values similar to that of controls after exacerbation treatment [58]. A significant decrease of $\alpha$ and $\beta$-carotenes has also been described in plasma of COPD patients compared to healthy controls [84].

The levels of essential trace elements, playing a role in oxidant/antioxidant pathways have also been determined. In particular, the plasma levels of selenium (Se) and zinc $(\mathrm{Zn})$, determined by inductively coupled plasma-mass spectroscopy, have been evaluated, finding decreased levels in COPD compared to controls [62]. Measuring Se, $\mathrm{Zn}$, iron $(\mathrm{Fe})$, copper $(\mathrm{Cu})$, potassium $(\mathrm{K})$, rubidium $(\mathrm{Rb})$ and calcium $(\mathrm{Ca})$ by particle-induced $\mathrm{X}$-ray emission, a reduction of $\mathrm{K}$ and Se and an increase of $\mathrm{Fe}, \mathrm{Ca}, \mathrm{Cu}, \mathrm{Zn}$ and $\mathrm{Rb}$ has been described in plasma, while in the blood cells of the same COPD patients a reduction of $\mathrm{K}$ and $\mathrm{Rb}$ and an increase of the other elements studied has been described [69]. Measuring $\mathrm{Cu}$ and $\mathrm{Zn}$ by means of atomic absorption spectrophotometry a significant increase of $\mathrm{Cu}$ and no difference for $\mathrm{Zn}$ has been found [44].

\section{Uric acid}

Uric acid is a powerful antioxidant that protects lipoproteins from oxidation and acts as a powerful scavenger of individual oxygen radicals and hydroxyl radicals. Significantly decreased levels of uric acid have been found by means of an enzymatic method using a colorimetric assay in plasma of COPD subjects compared to healthy controls [97] whereas a significant decrease was found only in very-severe COPD by HPLC with electrochemical detection [95]. No difference has been found using an automated analyzer [49].

\section{Total antioxidant capacity}

Given the difficult to measure each antioxidant separately, several methods have been developed and used to determine the total antioxidant capacities of various biological samples [98]. Some of these methods have been applied to determine the total antioxidant status in the plasma of COPD patients, in particular the FRAP (ferric reducing ability of plasma) and the TEAC (Trolox Equivalent Antioxidant Capacity) assay.

The FRAP assay is based on the ability of plasma to reduce a ferric tripyridyltriazine $\left(\mathrm{Fe}^{3+}-\mathrm{TPTZ}\right)$ complex to the ferrous tripyridyltriazine $\left(\mathrm{Fe}^{2+}-\mathrm{TPTZ}\right)$, whose intensive blue color can be monitored at $593 \mathrm{~nm}$.

The TEAC assay is based on the inhibition by antioxidants of the absorbance of the radical cation of 2,2'-azinobis (3-ethylbenzothiazoline 6-sulfonate) (ABTS), which has maximal absorption at 660,734 , and $820 \mathrm{~nm}$. The ABTS radical cation is formed when ABTS is incubated with the peroxidase metmyoglobin and $\mathrm{H}_{2} \mathrm{O}_{2}$. Upon the addition of a plasma sample, the oxidative reactions are suppressed by the antioxidant capacity of the plasma, preventing the color change.

Using the FRAP assay a significant decrease of total antioxidant capacity has been found in COPD patients compared to controls $[29,36]$ in relation also to disease progression $[29,36,96]$.

Using the TEAC assay, a significant decrease of total antioxidant capacity $[40,54,92,97,99,100]$ as well as no significant difference [49] has been described in COPD compared to controls. Moreover, other authors found a significant reduction only in exacerbated COPD [39]. The TEAC assay has been used also to investigate this biomarker in relation to disease progression, finding no difference throughout the various stages of the disease [40]. By means of another assay based on preventing the oxidation of ortho-dianisidine molecules into dianisidyl radicals by hydroxyl radicals, a significant decrease of total antioxidant potential has been described 
in COPD compared to controls [79]. A significant decrease of total antioxidant capacity has also been found by means of another kind of assay [31,32] that is based on preventing the oxidation of ortho-dianisidine molecules into dianisidyl radicals by hydroxyl radicals $\mathrm{OH}^{-}$.

\section{Enzymatic antioxidant activity}

Some antioxidant enzymes have been widely studied in blood of COPD patients such as superoxide dismutase (SOD), catalase and glutathione peroxidase (GSH-Px). To a lesser extent, the activities of glutathione-S-transferase (GST), paraoxonase 1 (PON1) and ceruloplasmin ferroxidase have also been studied.

\section{SOD activity}

SOD catalyzes dismutation of the $\mathrm{O}_{2}^{-}$to molecular oxygen and $\mathrm{H}_{2} \mathrm{O}_{2}$. In most studies SOD activity has been measured in COPD erythrocytes with the Mc Cord and Fridovich assay [101] finding different results (Table 1). On this method xanthine and xanthine oxidase are used to generate $\mathrm{O}_{2}^{-}$and 2-(4- iodophenyl)-3-(4-nitrophenol)-5-phenyltetrazolium chloride which reacts with $\mathrm{O}_{2}^{-}$to form red formazan dye. SOD inhibits this reaction and the activity is measured as percent inhibition. Using this method, either an increase $[36,69]$ or a decrease $[99,100]$ of erythrocytes SOD activity, as well as no difference [33] has been found in COPD versus controls (Table 1). No differences have also been found comparing moderate and severe COPD [46] (Table 1). Moreover, an increase in erythrocytes SOD activity has been observed only in exacerbated COPD [38].

Other assays measure SOD activity taking advantage of its ability to inhibit various reactions such as the auto oxidation of epinephrine to adrenochrome [102], the auto oxidation of pyrogallol [103] and the nitrite formation subsequent to reactions of $\mathrm{O}_{2}$ - with hydroxylamine hydrochloride [104]. The use of these assays brought different results. It has been found both a decrease $[26,29,30]$ and an increase [27] of erythrocyte SOD activity as well as no difference compared to controls [40] (Table 1).

SOD activity has been determined also in plasma of COPD patients using assays based on the inhibition of red formazan dye formation, finding an increase of SOD activity [61], a decrease of SOD activity [32, 41] and no difference [70, 71] compared to controls, as well as no difference throughout the stages of the disease [47] (Table 1). Estimating SOD with an ELISA kit, a significant reduction has been found in COPD subjects compared to controls [105] (Table 1).

\section{CATALASE activity}

Catalase is involved in the detoxification of $\mathrm{H}_{2} \mathrm{O}_{2}$ into molecular oxygen and water. Its activity has been measured in COPD erythrocytes using different methods based on monitoring the decomposition rate of $\mathrm{H}_{2} \mathrm{O}_{2}$ at
$240 \mathrm{~nm}$. In such way, both a decrease [26, 29, 99, 100] and no difference $[27,33,36,40]$ of catalase activity has been observed in COPD compared to controls (Table 1). Studying catalase activity in relation to disease progression has also brought different results, namely a significant decrease from moderate to severe COPD [26] as well as no difference either comparing moderate and severe COPD [46] or comparing all the stages of the disease [40] (Table 1). Catalase activity has been measured also in plasma in few studies where both a decrease [34, 43] and no significant difference $[47,71]$ has been observed in COPD compared to controls (Table 1). Moreover, estimating the enzyme activity with an ELISA kit, no significant difference has been found [105] (Table 1).

\section{GSHPx activity}

GSHPx activity converts reduced GSH to GSSG while reducing organic peroxides into their corresponding alcohols or $\mathrm{H}_{2} \mathrm{O}_{2}$ into water. Its activity has been measured in plasma, in total blood and especially in erythrocytes evaluating at $340 \mathrm{~nm}$ the oxidation of nicotinamide adenine dinucleotide phosphate (NADPH), a coenzyme in the reaction catalyzed by glutathione reductase that reduces GSSG formed during the activities catalized by GSHPx.

In most of the studies a decreased GSHPx activity in COPD erythrocytes has been described compared to controls $[26,27,29,33,36,99]$ as well as in relation to disease severity $[46,106]$ (Table 1$)$.

A decreased GSHPx activity has been observed analyzing COPD total blood [69] and plasma [34, 41, 43] (Table 1). In plasma, no difference in GSHPx activity [61] as well as an increase either monitoring the rate of NADPH oxidation $[36,105]$ or assaying the content of reduced GSH [40] has also been observed (Table 1).

\section{GST, PON 1 and ceruloplasmin ferroxidase activities}

GST catalyzes the inactivation of reactive electrophiles through their conjugation with GSH while PON1, an esterase associated with high-density lipoprotein (HDL), protects against the toxicity of some organophosphates and contributes to the antioxidant protection conferred by HDL on low-density lipoprotein oxidation. GST activity has been studied using 1-chloro-2,4-dinitrobenzene as an artificial substrate in plasma of COPD finding a decreased activity [99] and no differences compared to controls [61] as well as in erythrocytes [26] where a decreased enzymatic activity has been described.

PON1 activity has been evaluated in plasma of COPD using a two-substrate activity (paraoxon/diazoxon) method or by the hydrolysis of paraoxon alone. Using the first method no significant difference has been described in COPD compared to controls [32, 78]. Using the paraoxon method, a significant decreased enzyme activity has been described, either in COPD versus controls [44] 
and in the different stages of severity of disease [59]. No significant difference was found when only mild COPD was considered [55].

Ceruloplasmin is an important contributor to plasma antioxidant activity that includes ferroxidase activity, GSH-Px activity and the ability to scavenge ROS [107]. Its oxidase activity has been investigated in plasma of COPD subjects by means of an assay that works on its ability to oxidize ferrous ion to ferric ion, complexing with a chromogen that can be measured at $376 \mathrm{~nm}$. With this technique, a significant increase of the enzyme activity in COPD has been found [105] as well as no significant difference [100]. By means of immunonephelometry on an automated analyzer a significant increase of ceruloplasmin was found in COPD [56].

\section{Y-glutamyltransferase (GGT) activity}

GGT is a plasma membrane enzyme, which is involved in antioxidant glutathione resynthesis. Serum GGT levels are increased in a number of diseases that are known to have oxidative stress in the pathogenesis, suggesting that GGT levels can be considered a marker of oxidative stress $[108,109]$. GGT activity has been investigated in plasma of COPD patients. By using standardized methods on automatic analyzer, a significant increase of the enzyme activity has been found in COPD compared to healthy controls [110] as well as no difference [111]. A significant increase of GGT activity has also been found in exacerbated COPD compared to stable state [112] whereas no differences have been found in the different stages of the severity of the disease [110].

\section{Conclusions}

In this review we have summarized the main findings about the most studied circulating biomarkers of oxidative stress in COPD subjects, grouping them depending on the method of detection that could be useful for those who wants to deal with this issue.

Although oxidative stress has been largely studied in COPD, we still lack standardized biomarkers useful in diagnosis and in monitoring the progression of the disease. What emerges from literature is that lipid peroxidation products are the most studied as biomarkers of oxidative stress in COPD, especially MDA. In most cases it has been reported an increase of this marker either as MDA or as lipid peroxides, 8-isoprostane, conjugated dienes or oxidized LDL.

Other oxidative stress biomarkers that have often been studied in plasma of COPD patients are protein oxidation products, in particular protein carbonyls that have been described increased in about $85 \%$ of the studies. A marker of oxidative stress that, to our knowledge, has been described always increased in the examined casecontrol studies is superoxide anion, even if different assays have been used to investigate this marker. In addition, total oxidative status has been described always increased as well, by means of two types of assays and also in mild COPD.

Interestingly, concordant results have been found for these oxidative stress biomarkers at least in $80 \%$, if not in all of the examined studies, even using different methods of analysis. The explanation of why, in some cases, the remaining $20 \%$ of the studies gave different results is probably due to a different preanalytical approach, e.g. the sample collection, the time that elapses between collection of the sample and separation of serum from the blood cells, and the storage of the sample (temperature storage, container used for storage and repeated thawing). We must also consider the biological variability, due to age, sex, race and genetic selection. All of these variables unavoidably influence the measurement. Regarding antioxidant markers, protein and non protein $\mathrm{SH}$ groups have been largely investigated giving different results especially for the latters that have been studied in plasma, in erythrocytes and in whole blood. Nevertheless, protein $\mathrm{SH}$ groups and plasma reduced GSH have been described reduced in about the $80 \%$ of the examined studies. Considering total antioxidant capacity, $85 \%$ of the examined studies have reported a significant decrease of this parameter in COPD using different methods of analysis. On the contrary, conflicting results have been found analyzing the levels of antioxidant nutrients, such as vitamins $\mathrm{A}, \mathrm{C}$ and $\mathrm{E}$, and the enzymatic antioxidant activities. In fact, some authors have found a significant decrease of these biomarkers, while others have found no significant difference.

These conflicting findings could be due not only to the reasons explained above regarding the pre-analytical steps, but also to the fact that studies were carried out in different populations, and that there may be differences and inter-individual variations in antioxidant capacity, also due to cigarette smoke and its effect on the imbalance between oxidants and antioxidants.

From an overall point of view, despite the difficulties in reproducing the same results using different assays in different research laboratories, the findings summarized in this review highlight that literature is quite concordant in concluding that the blood of COPD patients presents an increase of oxidants and a decrease in some antioxidant defences compared to controls.

Up to now a large number of biomarkers have been evaluated in COPD, but their relative importance is not yet clearly understood. Hence, there is clearly the need to identify suitable biomarkers able to detect disease, to monitor disease progression, exacerbations and response to therapy. For this purpose, the choice of peripheral blood among other biological matrices, seems to be more appropriate given the non invasiveness of the blood sampling, its property of easily allowing repeated measurements and its 
effectiveness in monitoring systemic effects such as oxidative stress. Surely, further research is needed to validate such markers and a great effort should be done to better characterize subjects under study and to understand the issues that likely influence the measurements. Anyhow, this review is an important step in this context providing a comprehensive overview of the oxidative stress biomarkers evaluated in the blood of COPD subjects, stressing their potential utility in supporting diagnostic and therapeutic decisions.

\begin{abstract}
Abbreviations
8-oxodG: 8-oxo-7,8-dihydro-2'-deoxyguanosine; ABTS: 2,2'-azinobis (3ethylbenzothiazoline 6-sulfonate); AOPP: Advanced oxidation protein products; Ca: Calcium; CAT: Catalase; COPD: Chronic obstructive pulmonary disease; Cu: Copper; DNP: Dinitrophenylhydrazone; DNPH: 2,4-dinitrophenylhydrazine; ELISA: Enzyme linked immunosorbent assay; Fe: Iron; FRAP: Ferric reducing ability of plasma; GSH: Glutathione; GSH-Px: Glutathione peroxidase; GSSG: Oxidize glutathione; GST: Glutathione-S-transferase; $\mathrm{H}_{2} \mathrm{O}_{2}$ : Hydrogen peroxide; HDL: High-density lipoprotein; HPLC: High performance liquid chromatography; K: Potassium; MDA: Malondialdehyde; NADPH: Nicotinamide adenine dinucleotide phosphate; $\mathrm{O}_{2}^{-}$: Superoxide anion; $\mathrm{OH}^{-}$: Hydroxyl radical; PON1: Paraoxonase 1; Rb: Rubidium; ROMs: Reactive oxygen metabolites; ROS: Reactive oxygen species; Se: Selenium; -SH: Sulfhydryl group; SOD: Superoxide dismutase; TBA: Thiobarbituric acid; TBARS: Thiobarbituric acid reactive substances; TEAC: Trolox Equivalent Antioxidant Capacity; TOS: Total oxidative status; TP: Total peroxide; Zn: Zinc
\end{abstract}

\section{Acknowledgements}

Not applicable.

Funding

Not applicable.

\section{Availability of data and materials}

Not applicable.

\section{Authors' contributions}

EZ performed literature search and was responsible for data extraction. PP designed the project of this review and supervised EZ. EZ, AZ, AGF, CC, PP contributed to the drafting of the manuscript. All authors read and approved the final manuscript.

\section{Competing interests}

The authors declare that they have no competing interests.

\section{Consent for publication}

Not applicable.

\section{Ethics approval and consent to participate}

Not applicable.

\section{Author details}

${ }^{1}$ Department of Respiratory Diseases, Azienda Ospedaliero Universitaria di Sassari, Sassari, Italy. ${ }^{2}$ Department of Biomedical Sciences, University of Sassari, Sassari, Italy. ${ }^{3}$ Quality Control Unit, University Hospital of Sassari (AOU SS); Department of Biomedical Sciences, University of Sassari, Sassari, Italy.

Received: 29 July 2016 Accepted: 4 November 2016

Published online: 14 November 2016

\section{References}

1. Lozano R, Naghavi M, Foreman K, Lim S, Shibuya K, Aboyans V, Abraham J, Adair T, Aggarwal R, et al. Global and regional mortality from 235 causes of death for 20 age groups in 1990 and 2010: a systematic analysis for the Global Burden of Disease Study 2010. Lancet. 2012;380(9859):2095-128.

2. Decramer $M$, Janssens $W$, Miravitlles M. Chronic obstructive pulmonary disease. Lancet. 2012;379:1341-51.
3. Gold PM. The 2007 GOLD Guidelines: a comprehensive care framework. Respir Care. 2009;54:1040-9.

4. Barnes PJ. Chronic obstructive pulmonary disease. N Engl J Med. 2000; 343:269-80.

5. Gooptu B, Ekeowa UI, Lomas DA. Mechanisms of emphysema in alpha1antitrypsin deficiency: molecular and cellular insights. Eur Respir J. 2009; 34:475-88.

6. Mannino DM, Buist AS. Global burden of COPD: risk factors, prevalence, and future trends. Lancet. 2007;370:765-73.

7. Eisner MD, Anthonisen N, Coultas D, Kuenzli N, Perez-Padilla R, Postma D, Romieu I, Silverman EK, Balmes JR, Committee on Nonsmoking COPD, Environmental and Occupational Health Assembly. An official American Thoracic Society public policy statement: novel risk factors and the global burden of chronic obstructive pulmonary disease. Am J Respir Crit Care Med. 2010;182:693-718.

8. Pryor WA, Stone K. Oxidants in cigarette smoke: radicals, hydrogen peroxides, peroxynitrate, and peroxynitrite. Ann N Y Acad Sci. 1993;686:12-28.

9. Larsson K. Aspects on pathophysiological mechanisms in COPD. J Intern Med. 2007:262:311-40.

10. Rahman I, Biswas SK, Kode A. Oxidant and antioxidant balance in the airways and airway diseases. Eur J Pharmacol. 2006:533:222-39.

11. Kirkham PA, Barnes PJ. Oxidative stress in COPD. Chest. 2013;144(1):266-73.

12. MacNee W. Oxidative stress and lung inflammation in airways disease. Eur J Pharmacol. 2001;429:195-207.

13. MacNee W. Pulmonary and systemic oxidant/antioxidant imbalance in chronic obstructive pulmonary disease. Proc Am Thorac Soc. 2005;2:50-60.

14. Fischer BM, Voynow JA, Ghio AJ. COPD: balancing oxidants and antioxidants. Int J Chron Obstruct Pulmon Dis. 2015;10:261-76.

15. Dalle-Donne I, Rossi R, Colombo R, Giustarini D, Milzani A. Biomarkers of oxidative damage in human disease. Clin Chem. 2006;52:601-23.

16. Niki E. Lipid peroxidation: physiological levels and dual biological effects. Free Radic Biol Med. 2009:47:469-84.

17. Niki E. Lipid peroxidation products as oxidative stress biomarkers. Biofactors. 2008;34:171-80.

18. Giustarini D, Dalle-Donne I, Tsikas D, Rossi R. Oxidative stress and human diseases: origin, link, measurement, mechanisms, and biomarker. Crit Rev Clin Lab Sci. 2009;46:241-81.

19. Yin $H, X u L$, Porter NA. Free radical lipid peroxidation: mechanisms and analysis. Chem Rev. 2011;111:5944-72.

20. Niki E, Yoshida Y, Saito Y, Noguchi N. Lipid peroxidation: Mechanisms, inhibition, and biological effects. Biochem Biophys Res Commun. 2005;338:668-76.

21. Iuliano L, Micheletta F, Natoli S, Ginanni Corradini S, lappelli M, Elisei W, Giovannelli L, Violi F, Diczfalusy U. Measurement of oxysterols and alphatocopherol in plasma and tissue samples as indices of oxidant stress status. Anal Biochem. 2003:312:217-23.

22. Niki E. Biomarkers of lipid peroxidation in clinical material. Biochim Biophys Acta. 1840;2014:809-17

23. Lykkesfeldt J. Malondialdehyde as biomarker of oxidative damage to lipids caused by smoking. Clin Chim Acta. 2007;380:50-8.

24. Del Rio D, Stewart AJ, Pellegrini N. A review of recent studies on malondialdehyde as toxic molecule and biological marker of oxidative stress. Nutr Metab Cardiovasc Dis. 2005;15:316-28.

25. Dhakal N, Lamsal M, Baral N, Shrestha S, Dhakal SS, Bhatta N, Dubey RK. Oxidative stress and nutritional status in chronic obstructive pulmonary disease. J Clin Diagn Res. 2015;9:BC01-4.

26. Arja C, Surapaneni KM, Raya P, Adimoolam C, Balisetty B, Kanala KR. Oxidative stress and antioxidant enzyme activity in South Indian male smokers with chronic obstructive pulmonary disease. Respirology. 2013;18:1069-75.

27. Woźniak A, Górecki D, Szpinda M, Mila-Kierzenkowska C, Woźniak B. Oxidant-antioxidant balance in the blood of patients with chronic obstructive pulmonary disease after smoking cessation. Oxid Med Cell Longev. 2013;2013:897075.

28. Cristóvão C, Cristóvão L, Nogueira F, Bicho M. Evaluation of the oxidant and antioxidant balance in the pathogenesis of chronic obstructive pulmonary disease. Rev Port Pneumol. 2013;19:70-5.

29. Ahmad A, Shameem M, Husain Q. Altered oxidant-antioxidant levels in the disease prognosis of chronic obstructive pulmonary disease. Int J Tuberc Lung Dis. 2013;17:1104-9.

30. Raut AM, Suryakar AN, Mhaisekar D. A study of oxidative stress, thiol proteins and role of vitamin $\mathrm{E}$ supplementation in chronic obstructive pulmonary disease (COPD). Al Ameen J Med Sci. 2013;6:134-7. 
31. Gencer M, Aksoy N, Dagli EC, Uzer E, Aksoy S, Selek S, Celik H, Cakir H. Prolidase activity dysregulation and its correlation with oxidativeantioxidative status in chronic obstructive pulmonary disease. J Clin Lab Anal. 2011;25:8-13.

32. Stanojkovic I, Kotur-Stevuljevic J, Milenkovic B, Spasic S, Vujic T, Stefanovic A, Llic A, Ivanisevic J. Pulmonary function, oxidative stress and inflammatory markers in severe COPD exacerbation. Respir Med. 2011;105:S31-7.

33. Joppa P, Petrásová D, Stancák B, Dorková Z, Tkácová R. Oxidative stress in patients with COPD and pulmonary hypertension. Wien Klin Wochenschr. 2007;119:428-34.

34. Vibhuti A, Arif E, Deepak D, Singh B, Qadar Pasha MA. Correlation of oxidative status with BMl and lung function in COPD. Clin Biochem. 2007;40:958-63.

35. Ceylan E, Kocyigit A, Gencer M, Aksoy N, Selek S. Increased DNA damage in patients with chronic obstructive pulmonary disease who had once smoked or been exposed to biomass. Respir Med. 2006;100:1270-6.

36. Nadeem A, Raj HG, Chhabra SK. Increased oxidative stress and altered levels of antioxidants in chronic obstructive pulmonary disease. Inflammation. 2005;29:23-32.

37. Calikoğlu M, Unlü A, Tamer L, Ercan B, Buğdayci R, Atik U. The levels of serum vitamin $C$, malonyldialdehyde and erythrocyte reduced glutathione in chronic obstructive pulmonary disease and in healthy smokers. Clin Chem Lab Med. 2002;40:1028-31.

38. Hanta I, Kocabas A, Canacankatan N, Kuleci S, Seydaoglu G. Oxidantantioxidant balance in patients with COPD. Lung. 2006;184:51-5.

39. Rahman I, Morrison D, Donaldson K, MacNee W. Systemic oxidative stress in asthma, COPD, and smokers. Am J Respir Crit Care Med. 1996;154:1055-60.

40. ben Anes A, Fetoui H, Bchir S, ben Nasr H, Chahdoura H, Chabchoub E, Yacoub S, Garrouch A, Benzarti M, Tabka Z, Chahed K. Increased oxidative stress and altered levels of nitric oxide and peroxynitrite in Tunisian patients with chronic obstructive pulmonary disease: correlation with disease severity and airflow obstruction. Biol Trace Elem Res. 2014;161:20-31.

41. Zeng M, Li Y, Jiang Y, Lu G, Huang X, Guan K. Local and systemic oxidative stress status in chronic obstructive pulmonary disease patients. Can Respir J. 2013;20:35-41.

42. Tsukagoshi H, Shimizu Y, Iwamae S, Hisada T, Ishizuka T, lizuka K, Dobashi K, Mori M. Evidence of oxidative stress in asthma and COPD: potential inhibitory effect of theophylline. Respir Med. 2000;94:584-8.

43. Vibhuti A, Arif E, Mishra A, Deepak D, Singh B, Rahman I, Mohammad G, Pasha MA. CYP1A1, CYP1A2 and CYBA gene polymorphisms associated with oxidative stress in COPD. Clin Chim Acta. 2010;411:474-80.

44. Isik B, Isik RS, Ceylan A, Calik O. Trace elements and oxidative stress in chronic obstructive pulmonary disease. Saudi Med J. 2005;26:1882-5.

45. Premanand R, Kumar S, Mohan A. Study of thiobarbituric reactive substances and total reduced glutathione as indices of oxidative stress in chronic smokers with and without chronic obstructive pulmonary disease. Indian J Chest Dis Allied Sci. 2007:49:9-12.

46. Kluchová Z, Petrásová D, Joppa P, Dorková Z, Tkácová R. The association between oxidative stress and obstructive lung impairment in patients with COPD. Physiol Res. 2007;56:51-6.

47. Folchini F, Nonato NL, Feofiloff E, D'Almeida V, Nascimento O, Jardim JR. Association of oxidative stress markers and C-reactive protein with multidimensional indexes in COPD. Chron Respir Dis. 2011;8:101-8.

48. Jammes Y, Steinberg JG, Ba A, Delliaux S, Brégeon F. Enhanced exerciseinduced plasma cytokine response and oxidative stress in COPD patients depend on blood oxygenation. Clin Physiol Funct Imaging. 2008;28:182-8.

49. Koechlin C, Couillard A, Cristol JP, Chanez P, Hayot M, Le Gallais D, Préfaut C. Does systemic inflammation trigger local exercise-induced oxidative stress in COPD? Eur Respir J. 2004;23:538-44.

50. Couillard A, Koechlin C, Cristol JP, Varray A, Prefaut C. Evidence of local exercise-induced systemic oxidative stress in chronic obstructive pulmonary disease patients. Eur Respir J. 2002;20:1123-9.

51. Erden ES, Motor S, Ustun I, Demirkose M, Yuksel R, Okur R, Oktar S, Yakar Y, Sungur S, Gokce C. Investigation of Bisphenol A as an endocrine disruptor, total thiol, malondialdehyde, and C-reactive protein levels in chronic obstructive pulmonary disease. Eur Rev Med Pharmacol Sci. 2014;18:3477-83.

52. Torres-Ramos YD, García-Guillen ML, Olivares-Corichi IM, Hicks JJ. Correlation of plasma protein carbonyls and C-reactive protein with GOLD stage progression in COPD patients. Open Respir Med J. 2009;3:61-6.

53. Ben Moussa S, Sfaxi I, Tabka Z, Ben Saad H, Rouatbi S. Oxidative stress and lung function profiles of male smokers free from COPD compared to those with COPD: a case-control study. Libyan J Med. 2014;9:23873.
54. Rahman I, Skwarska E, MacNee W. Attenuation of oxidant/antioxidant imbalance during treatment of exacerbations of chronic obstructive pulmonary disease. Thorax. 1997;52:565-8.

55. Zinellu A, Fois AG, Sotgia S, Zinellu E, Bifulco F, Pintus G, Mangoni AA, Carru C, Pirina P. Plasma protein thiols: an early marker of oxidative stress in asthma and chronic obstructive pulmonary disease. Eur J Clin Invest. 2016;46:181-8.

56. Milevoj Kopčinović L, Domijan AM, Posavac K, Čepelak I, Žanić Grubišić T, Rumora L. Systemic redox imbalance in stable chronic obstructive pulmonary disease. Biomarkers. 2016:28:1-7.

57. Sunnetcioglu A, Alp HH, Sertogullarından B, Balaharoglu R, Gunbatar H. Evaluation of oxidative damage and antioxidant mechanisms in COPD, lung cancer, and obstructive sleep apnea syndrome. Respir Care. 2016;61:205-11.

58. Tug T, Karatas F, Terzi SM. Antioxidant vitamins (A, C and E) and malondialdehyde levels in acute exacerbation and stable periods of patients with chronic obstructive pulmonary disease. Clin Invest Med. 2004;27:123-8.

59. Torres-Ramos YD, Guzman-Grenfell AM, Montoya-Estrada A, RamirezVenegas A, Martinez RS, Flores-Trujillo F, Ochoa-Cautino L, Hicks JJ. RBC membrane damage and decreased band 3 phospho-tyrosine phosphatase activity are markers of COPD progression. Front Biosci. 2010;2:1385-93.

60. Guzmán-Grenfell A, Nieto-Velázquez N, Torres-Ramos Y, Montoya-Estrada A, Ramírez-Venegas A, Ochoa-Cautiño L, Flores-Trujillo F, Hicks JJ. Increased platelet and erythrocyte arginase activity in chronic obstructive pulmonary disease associated with tobacco or wood smoke exposure. J Investig Med. 2011:59:587-92.

61. Montaño M, Cisneros J, Ramírez-Venegas A, Pedraza-Chaverri J, Mercado D, Ramos C, Sansores RH. Malondialdehyde and superoxide dismutase correlate with FEV(1) in patients with COPD associated with wood smoke exposure and tobacco smoking. Inhal Toxicol. 2010;22:868-74.

62. Maury J, Gouzi F, De Rigal P, Heraud N, Pincemail J, Molinari N, Pomiès P, Laoudj-Chenivesse D, Mercier J, Préfaut C, Hayot M. Heterogeneity of systemic oxidative stress profiles in COPD: a potential role of gender. Oxid Med Cell Longev. 2015;2015:201843.

63. Kaźmierczak M, Ciebiada M, Pękala-Wojciechowska A, Pawłowski M, Nielepkowicz-Goździńska A, Antczak A. Evaluation of markers of inflammation and oxidative stress in COPD patients with or without cardiovascular comorbidities. Heart Lung Circ. 2015;24:817-23.

64. Berlett BS, Stadtman ER. Protein oxidation in aging, disease and oxidative stress. J Biol Chem. 1997;272:20313-6.

65. Dalle-Donne I, Rossi R, Giustarini D, Milzani A, Colombo R. Protein carbonyl groups as biomarkers of oxidative stress. Clin Chim Acta. 2003;329:23-38.

66. Chevion M, Berenshtein E, Stadtman ER. Human studies related to protein oxidation: protein carbonyl content as a marker of damage. Free Radic Res. 2000;33:99-108.

67. Levine RL. Carbonyl modified proteins in cellular regulation, aging, and disease. Free Radic Biol Med. 2002;32:790-6.

68. Stadtman ER, Levine RL. Free radical-mediated oxidation of free amino acids and amino acid residues in proteins. Amino Acids. 2003;25:207-18.

69. Santos MC, Oliveira AL, Viegas-Crespo AM, Vicente L, Barreiros A, Monteiro $P$, Pinheiro T, Bugalho De Almeida A. Systemic markers of the redox balance in chronic obstructive pulmonary disease. Biomarkers. 2004;9:461-9.

70. Puig-Vilanova E, Rodriguez DA, Lloreta J, Ausin P, Pascual-Guardia S, Broquetas J, Roca J, Gea J, Barreiro E. Oxidative stress, redox signaling pathways, and autophagy in cachectic muscles of male patients with advanced COPD and lung cancer. Free Radic Biol Med. 2015;79:91-108.

71. Barreiro E, Fermoselle C, Mateu-Jimenez M, Sánchez-Font A, Pijuan L, Gea J, Curull V. Oxidative stress and inflammation in the normal airways and blood of patients with lung cancer and COPD. Free Radic Biol Med. 2013;65:859-71.

72. Rodriguez DA, Kalko S, Puig-Vilanova E, Perez-Olabarría M, Falciani F, Gea J, Cascante M, Barreiro E, Roca J. Muscle and blood redox status after exercise training in severe COPD patients. Free Radic Biol Med. 2012;52:88-94.

73. Gopal P, Reynaert NL, Scheijen JL, Engelen L, Schalkwijk CG, Franssen FM, Wouters EF, Rutten EP. Plasma advanced glycation end-products and skin autofluorescence are increased in COPD. Eur Respir J. 2014:43:430-8.

74. Cao W, Hou FF, Nie J. AOPPs and the progression of kidney disease. Kidney Int Suppl (2011). 2014;4:102-6.

75. Witko-Sarsat V, Friedlander M, Capeillère-Blandin C, Nguyen-Khoa T, Nguyen AT, Zingraff J, Jungers P, Descamps-Latscha B. Advanced oxidation protein products as a novel marker of oxidative stress in uremia. Kidney Int. 1996;49:1304-13.

76. Münzel T, Afanas'ev IB, Kleschyov AL, Harrison DG. Detection of superoxide in vascular tissue. Arterioscler Thromb Vasc Biol. 2002;22:1761-8. 
77. Erel O. A new automated colorimetric method for measuring total oxidant status. Clin Biochem. 2005;38:1103-11.

78. Stanojkovic I, Kotur-Stevuljevic J, Spasic S, Milenkovic B, Vujic T, Stefanovic A, Ivanisevic J. Relationship between bone resorption, oxidative stress and inflammation in severe COPD exacerbation. Clin Biochem. 2013;46:1678-82.

79. Ceylan E, Gencer M, Uzer E, Celik H. Measurement of the total antioxidant potential in chronic obstructive pulmonary diseases with a novel automated method. Saudi Med J. 2007;28:1339-43.

80. Ekin S, Arısoy A, Gunbatar H, Sertogullarindan B, Sunnetcioglu A, Sezen H, Asker S, Y I ld $\mathrm{z} H$. The relationships among the levels of oxidative and antioxidative parameters, FEV1 and prolidase activity in COPD. Redox Rep. 2016;15:1-4.

81. Foschino Barbaro MP, Carpagnano GE, Spanevello A, Cagnazzo MG, Barnes PJ. Inflammation, oxidative stress and systemic effects in mild chronic obstructive pulmonary disease. Int J Immunopathol Pharmacol. 2007;20:753-63.

82. Markoulis N, Gourgoulianis Kl, Moulas A, Gerogianni E, Molyvdas AP. Reactive oxygen metabolites as an index of chronic obstructive pulmonary disease severity. Panminerva Med. 2006;48:209-13.

83. Singh NP, McCoy MT, Tice RR, Schneider EL. A simple technique for quantitation of low levels of DNA damage in individual cells. Exp Cell Res. 1988;175:184-91.

84. Lin YC, Wu TC, Chen PY, Hsieh LY, Yeh SL. Comparison of plasma and intake levels of antioxidant nutrients in patients with chronic obstructive pulmonary disease and healthy people in Taiwan: a case-control study. Asia Pac J Clin Nutr. 2010;19:393-401.

85. Turell L, Radi R, Alvarez B. The thiol pool in human plasma: the central contribution of albumin to redox processes. Free Radic Biol Med. 2013:65:244-53.

86. Di Simplicio P, Cacace MG, Lusini L, Giannerini F, Giustarini D, Rossi R. Role of protein - $\mathrm{SH}$ groups in redox homeostasis-the erythrocyte as a model system. Arch Biochem Biophys. 1998;355:145-52.

87. Groitl B, Jakob U. Thiol-based redox switches. Biochim Biophys Acta. 1844; 2014:1335-43.

88. Jones DP, Carlson JL, Mody VC, Cai J, Lynn MJ, Sternberg P. Redox state of glutathione in human plasma. Free Radic Biol Med. 2000;28:625-35.

89. Jones DP. Redox potential of GSH/GSSG couple: assay and biological significance. Methods Enzymol. 2002;348:93-112.

90. Quinlan GJ, Martin GS, Evans TW. Albumin: biochemical properties and therapeutic potential. Hepatology. 2005:41:1211-9.

91. Ellman GL. Tissue sulfhydryl groups. Arch Biochem Biophys. 1959;82:70-7.

92. Rahman I, Swarska E, Henry M, Stolk J, MacNee W. Is there any relationship between plasma antioxidant capacity and lung function in smokers and in patients with chronic obstructive pulmonary disease? Thorax. 2000;55:189-93.

93. Tietze F. Enzymic method for quantitative determination of nanogram amounts of total and oxidized glutathione: applications to mammalian blood and other tissues. Anal Biochem. 1969:27:502-22.

94. Griffith OW. Determination of glutathione and glutathione disulfide using glutathione reductase and 2-vinylpyridine. Anal Biochem. 1980;106:207-12.

95. Nicks ME, O'Brien MM, Bowler RP. Plasma antioxidants are associated with impaired lung function and COPD exacerbations in smokers. COPD. 2011:8:264-9.

96. Pirabbasi E, Najafiyan M, Cheraghi M, Shahar S, Abdul Manaf Z, Rajab N, Abdul MR. What are the antioxidant status predictors' factors among male chronic obstructive pulmonary disease (COPD) patients? Glob J Health Sci. 2012;5:70-8.

97. Hageman GJ, Larik I, Pennings HJ, Haenen GR, Wouters EF, Bast A. Systemic poly(ADP-ribose) polymerase-1 activation, chronic inflammation, and oxidative stress in COPD patients. Free Radic Biol Med. 2003;35:140-8.

98. Prior RL, Cao G. In vivo total antioxidant capacity: comparison of different analytical methods. Free Radic Biol Med. 1999:27:1173-81.

99. Lakhdar R, Denden S, Mouhamed MH, Chalgoum A, Leban N, Knani J, Lefranc G, Miled A, Ben Chibani J, Khelil AH. Correlation of EPHX1, GSTP1, GSTM1, and GSTT1 genetic polymorphisms with antioxidative stress markers in chronic obstructive pulmonary disease. Exp Lung Res. 2011;37:195-204.

100. Tavilani H, Nadi E, Karimi J, Goodarzi MT. Oxidative stress in COPD patients, smokers, and non-smokers. Respir Care. 2012;57:2090-4.

101. McCord JM, Fridovich I. Superoxide dismutase. An enzymic function for erythrocuprein (hemocuprein). J Biol Chem. 1969;244:6049-55.

102. Misra HP, Fridovich I. The role of superoxide anion in the auto oxidation of epinephrine and a simple assay for super oxide dismutase. J Biol Chem. 1972;247:3170-5.

103. Marklund S, Marklund G. Involvement of the superoxide anion radical in the autoxidation of pyrogallol and a convenient assay for superoxide dismutase. Eur J Biochem. 1974;47:469-74.

104. Das K. A modified spectophotometric assay of suphoxide dismutase using nitrate formation by suphoxide radiacal. Ind J Biochem Biophysics. 2000;37:201-4.
105. Ambade VN, Sontakke AN, Barthwal MS, Tyagi R, Basannar DR. Diagnostic Utility of Biomarkers in COPD. Respir Care. 2015;60:1729-42.

106. Tkacova R, Kluchova Z, Joppa P, Petrasova D, Molcanyiova A. Systemic inflammation and systemic oxidative stress in patients with acute exacerbations of COPD. Respir Med. 2007;101:1670-6.

107. Healy J, Tipton K. Ceruloplasmin and what it might do. J Neural Transm (Vienna). 2007;114:777-81.

108. Lee DH, Blomhoff $\mathrm{R}$, Jacobs Jr DR. Is serum gamma glutamyltransferase a marker of oxidative stress? Free Radic Res. 2004;38:535-9.

109. Koenig G, Seneff S. Gamma-Glutamyltransferase: A Predictive Biomarker of Cellular Antioxidant Inadequacy and Disease Risk. Dis Markers. 2015; 2015:818570.

110. Biljak VR, Rumora L, Cepelak I, Pancirov D, Popović-Grle S, Sorić J, Stjepanović G, Grubisić TZ. Gamma-glutamyltransferase and C-reactive protein in stable chronic obstructive pulmonary disease. Coll Antropol. 2013;37:221-7.

111. Cepelak I, Dodig S, Romic D, Ruljancic N, Popovic-Grle S, Malic A. Enzyme catalytic activities in chronic obstructive pulmonary disease. Arch Med Res. 2006;37:624-9.

112. Ermis H, Celik MR, Gulbas G, Tavli D, Aytemur ZA. Relationship between serum Y-glutamyltransferase levels and acute exacerbation of chronic obstructive pulmonary disease. Pol Arch Med Wewn. 2013;123:85-90.

\section{Submit your next manuscript to BioMed Central and we will help you at every step:}

- We accept pre-submission inquiries

- Our selector tool helps you to find the most relevant journal

- We provide round the clock customer support

- Convenient online submission

- Thorough peer review

- Inclusion in PubMed and all major indexing services

- Maximum visibility for your research

Submit your manuscript at www.biomedcentral.com/submit
C) Biomed Central 